KAIROS ELT JOURNAL, Vol. 2, No. 2, August 2018

Copyright $\odot 2018$, ISSN: 2580-4278

\title{
TEACHING VOCABULARY THROUGH MIND MAPPING TECHNIQUE TO THE EIGHTH GRADE STUDENTS OF SMP SANTO THOMAS 3 MEDAN
}

\author{
Lilia Junita Sirait, Jontra Jusat Pangaribuan, Karisma E. Tarigan \\ Catholic University of Saint Thomas
}

\begin{abstract}
The aim of this study is to find whether Mind Mapping Technique works effectively on improving the eighth grade students' achievement in vocabulary and to know the students' responses after being taught by using Mind Mapping Technique. in order to achieve the objectives of study, a classroom action research was designed and carried out in this study. The subjects of this study were 27 students of class VIII- $8^{1}$ OF SMP Santo Thomas 3 Medan in academic year 2018/2019. Test, observation sheet, and field notes were used as a instruments for collecting data. The results of the study showed significant improvement of the students' vocabulary. It is proved by the students' mean score of each test: pre-test was $65,33 \%$, formative test was $72,59 \%$ and post-test was $85,92 \%$. In addition, the, the analysis result of the observation sheet and field notes showed Mind Mapping Technique channge the students' learning behavior being better than before. They were more enthusiastic during the teaching learning process in each cycle. The analysis result of questionnaire showed that Mind Mapping Technique was useful to most of students to improve their learnig interest in vocabulary. Based on the results of those study instruments, it can be concluded that Mind Mapping Technique as learning technique gives the improvement to students' vocabulary. It is recommended for English teacher to apply Mind Mapping Technique in teaching vocabulary in order to improve students' vocabulary.
\end{abstract}

Keywords: vocabulary and mind mapping technique

\section{INTRODUCTION}

Vocabulary is one of the important language aspects in learning English as a foreign language. Students cannot communicate their ideas as clearly as they would like to express because of their limited vocabulary. Therefore, the mastery of vocabulary would be much helpful to the students in learning a language.

Vocabulary is central to language and important to language learner. Without a sufficient vocabulary, students cannot communicate effectively or express his/her ideas in both oral and written forms. It means that for a good communication students should master English vocabulary and grammatical rules. Therefore, vocabulary can help the English teaching goals generally.

In teaching vocabulary, teachers often just follow the instruction in students' textbooks, such as explaining the material in the book, giving the students some examples and asking the questions in this book. Teacher shoned be able to use pictures, games or word puzzle in teaching vocabulary in order to attract the students' intereset. In this way can students enhance this vocabulary as the basis for communication because write out sufficient vocabulary, it will be difficult for them to communicate.

The fact shows that the implementation of English learning process still is difficult because the students have low interest in learning English. The teachers' technique is boring and some of the students are naughty and lazy to bring their dictionaries.

Teaching vocabulary well is a key aspect of developing engaged and successful readers. Vocabulary mastery should be the first priority in English language teaching and learning, because it is impossible for learners to perform well in English if their vocabulary is very poor. In reality, vocabulary becomes a problem to almost all of students at any level of education.

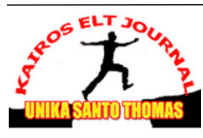


Vocabulary is assumed as one of the major difficult aspects of language to be mastered since there are many students who still struggle with mastering vocabulary. Because of that, the teacher should look for an effective technique to make learning vocabulary easier, more pleasant and enjoyable. English teachers should give the best way in teaching to make the students understand about the material. Teachers are developing strategy to make students interested in the material. Teaching techniques used by the teachers play important roles to achieve the success of learning.

There are many reasons why students have problems in mastering English vocabulary. First, students do not understand the meaning of the words. Therefore, they ignore all other function of the words. For instance, students usually acquire new vocabulary through new words in their textbooks or when given by teachers during classroom activities. For example, students find many new words in a text and then ask the teacher to explain the meaning and usages. Another problem is most of the teaching and learning vocabulary in the class is dominated by memorizing the words. This condition and situation cause some of the students feel bored and lazy to memorize vocabulary.

Based on the problems above, the writer is interested in giving a probable solution. To learn English vocabulary, the teachers should use many kinds of techniques in order to make the students master the lesson. One of the techniques which is used in teaching vocabulary is Mind Mapping technique. Jones et.al (2012: 2) states, "Mind mapping helps students learn information by forcing them to organize it and add images and color to it. It allows students to create a visual image to enhance their learning”. Thus, using Mind Mapping in teaching vocabulary is one way to avoid the students' boredom. In addition, Liu (2016:202-206) states "Mind mapping has simple and effective characteristics (Tonni Limbong, 2018). As a thinking tool with revolutionary nature, it uses the way of excellent picture and its accompanying essay to connect principal parts at all levels and shows words and expressions and vocabularies with membership function through hierarchical relationship and finding new tree-shaped relationship". Thus, using Mind Mapping in teaching vocabulary is a tool for students to discover the relationships between vocabulary words.

Based on the writer's experience during the Field Practice Experience (Praktek Pengalaman Lapangan), at SMP Santo Thomas 3 Medan at the Eighth Grade Students in the Academic Year of 2017/2018, the writer found some problems in teaching and learning process of vocabulary. First, in learning and teaching vocabulary, the teacher's technique used in teaching vocabulary was not interesting or monotonous. It made the students lazy to learn vocabulary. Second, students have problems in memorizing, pronouncing, and understanding the words and it makes them difficult in English study. Third, only few students in the classroom bring a dictionary in order that make their friends disturb in the learning activities. Last, the students prefer to be silent and be passive in the classroom activities when they do not understand the meaning of the word so the students wait the teacher to give explain the meaning of word.

The writer chooses this technique because some research finding have shown the good result of teaching vocabulary through Mind Mapping technique. The first research was conducted by Wisnawa (2013) entitled “ The Improving Vocabulary Mastery Through Mind Mapping of the Seventh Grade Students of SMP Silachandra in Academic Year 2012/2013". This research was focused on the use of Mind Mapping technique to improve the students' vocabulary. He stated that the use of Mind Mapping Technique is effective to be applied in teaching vocabulary. It makes students more interested and enjoyable during learning teaching process. The finding of the research showed that Mind Mapping Technique could improve students' vocabulary. It was seen from the improvement of students mean score from 70,01 in cycle I up to 73,57 in cycle II. Another research was conducted by Mamura (2011) entitled “ The Use of Mind Mapping to Improve Vocabulary Mastery of the Fourth Grade Students of

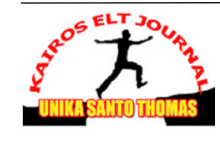


KAIROS ELT JOURNAL, Vol. 2, No. 2, August 2018

Copyright $\odot 2018$, ISSN: 2580-4278

SMP Muhammadiyah Ngijon 1 in the Academic Year of 20010/2011”. Based on the result of the this research, the implementation of Mind Mapping Technique could improve students' vocabulary mastery at the Fourth Grade Students of SMP Muhammadiyah Ngijon 1 in the Academic Year of 2010/2011. It was seen from the improvement of students' mean score from 50,69 in cycle I up to 89,04 in cycle II.

\section{REVIEW OF LITERATURE Vocabulary}

Vocabulary is one major component of a language learning which has to be mastered by the learners. According to Benjamin \& Crow (2009:2), vocabulary is the center for our ability to communicate or to absorb new knowledge. It means that it is impossible a person can express his/her ideas properly without a wide knowledge of English vocabulary.

Vocabulary is an essential one for students as their step to go on studying English. If we want to use language effectively, we must have good stock of vocabulary. We can not use the language, if we don't know the words. Nunan (2003:130) states that words are clearly vocabulary. She also adds that vocabulary is not only that, but it also words combination/multiple units, word families, and core meaning also are counted as vocabulary. A person cannot learn a language without learning vocabulary.

Vocabulary is the basis of acquiring and using the language. According to Linse (2005:121) vocabulary is a collection of words in a particular language that an individual knows and has a meaning. It means that a language consists of a number of words that are meaningful. It consists of some terms of words that can differentiate one language to another language. Vocabulary is the central element in a language that connects all efficient skills in speaking, listening, writing, or reading and will be useful if we understand the meaning of these words.

Having a limited vocabulary is like a barrier that prevents students from leaning a language. Schmitt (2000:22), Without a sufficient vocabulary, someone cannot commuicate effectively or express ideas because we think wit word. We also speak, listen, read, and write with words. Words help us communicate our ideas and they also help us to understand other people's ideas. It also implied that vocabulary takes an important role in improving our skills in English. A good vocabulary goes hand in hand with someone's ability to think logically and to learn easily and quickly.

\section{The Importance of Vocabulary}

Teaching vocabulary is a very challenging and interesting task for teacher. The teacher should be able to select the most appropriate way and tool to ensure the improvement of the students' vocabulary ability. Vocabulary is very important in learning language. Rubin (1993:7) states that vocabulary plays the most important role in learning English. Without basic vocabulary, there is very little we can do. In learning foreign language, it is necessary to mastery the vocabulary is crucial in language learning because it can support us to communicate.

Taylor (1990:1) states vocabularies important as a name of person or certain things, that is why cocabulary is important. By acquiring more vocabulary, the students can develop their ability to master the language and students will be able to understand the message of the text well. It is a fact that vocabulary mastery is needed for the learner especially to be able to communicate easily and fluently in the target language. However, if we want to be able to communicate with the other, especially with native speaker, we have to master of vocabulary.

According to Schmitt (2000:23), learners carry around dictionaries not grammar books to practice their English communication. In addition, Thornburry $(2002: 14)$ states that learning vocabulary is important because it enriches someone's knowledge of words. It means that although the students could use grammar without sufficient stock of vocabulary, they would

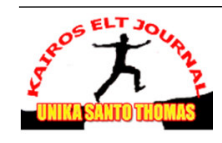


KAIROS ELT JOURNAL, Vol. 2, No. 2, August 2018

Copyright $\odot 2018$, ISSN: 2580-4278

get some problem in learning the language. In relation to the communication, one of the purposes of learning a vocabulary is to be able to use the language or the words in communication. Without a sufficient stock of the vocabulary, we will face the problem of expressing ideas and understand those ideas.

\section{Teaching Vocabulary}

To make good conversation in English not only the learners but also the teacher should have a good idea of how to expand their vocabulary in teaching learning process. Taeching vocabulary is one of the basic elements in achieving all four langauge skills. Jordan (1997:149) states that teaching vocabulary is such an important task in teaching English because vocabulary achievement relates to all language learning and it is of concern to all four language skills.

Capello \& Moss (2010:137) states that teaching vocabulary well is the key to developing a successful vocabulary. It means that teaching vocabulary is one of the ways to develop English competence of a person who is learning English because it is one of the success keys in learning. It plays an important role in language acquisition because the mastery of vocabulary will help students to master all the language skills: listening, speaking, reading, and writing. Without understanding the new words, the students will get the difficulties to studying English language.

Teachers needs a good knowledge on their teaching materials. When they have to teach the students about vocabulary, teachers should know the general knowledge of vocabulary, words, and also the meaning. Nation (1994:18) explains, when we teach a word we must teach three things: (1) we must teach the shape or form of the word, (2) we must teach the meaning of the word, (3) and we must teach the form and the meaning of the word go together. So, if we teach home, we must teach the learner to recognize or produce the word home, we must teach them what a home is, and we must teach them the sound or shape of home and the meaning.

\section{Kinds of Vocabulary}

Shepherd (1980:1) classifies vocabulary into two kinds: a receptive vocabulary and an expressive vocabulary (productive vocabulary). Further, he defines the receptive vocabulary as the words one knows when the learner listens and reads. The receptive vocabulary is also called a passive process because the learner only receives thought from others. In language application, the receptive vocabulary is considered as the basic vocabulary. Schrivener (1994:74) elaborates the two types of vocabulary as follows:

1. Receptive vocabulary is known as the words that are being able to recognize when it is heard or when it is seen has an expectation of what grammatical pattern of the world will be occurrence. A large number of items in receptive vocabulary are words that are very low frequency. Someone does not need to know much about the receptive vocabulary because someone rarely uses the receptive vocabulary and it is impossible for someone to memorize all the vocabularies of a certain language but someone can understand the ideas of the utterance contextually not word by word. Because of that condition, someone must know and understand more receptive vocabulary than productive one.

2. Productive vocabulary is known as the words that are being able to pronounce, how to write and to spell it, how to use it in grammatical pattern along with the word in usually collocates with it. Productive vocabulary is also used in appropriate situation. For instance, when we were talking to our friends in the class will be different from talking to people in a hotel. So, we can develop our vocabulary through out our whole lives. We can also learn new words and expanad our knowledge from our experiences. For example, cat, beautiful,

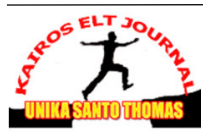


KAIROS ELT JOURNAL, Vol. 2, No. 2, August 2018

Copyright $\odot 2018$, ISSN: 2580-4278

manager, and so on. Thus, we produce the words and enrich our vocabularies through our lives and experiences that we have ever had.

\section{Vocabulary Teaching Technique}

Teaching and learning a foreign language needs a lot of patience, creativity and competence. The success of the teaching and learning process is determined by number of factors both linguistic and non linguistic such as the students, teacher, the methods or technique, material and media. Nation (2001:25) asserts that there are five essential steps in learning and teaching vocabulary: having sources for encountering new words,(2) getting a clear image whether it is visual or auditory or both for the forms of new words,(3) learning the meaning of the words, (4) making strong memory connection between the forms and meaning of the words,(5) and using of the words.

According to Richards \& Renandya (2002:260), technique is implementation which actually takes place in a classroom. In order to accomplish certain goal of teaching foreign language, a technique should be familiar to the teacher. There are some techniques that can be used in teaching vocabulary, such as: word webbing, semantic mapping, guesing words, anagram, clustering, mind mapping, and so on. Mind Mapping technique is considered as an appropriate technique in teaching vocabulary. It can be done not only in a serious manner but also in friendly way. That is way in this study, the writer apply mind mapping technique in teaching vocabulary. The purpose is to make the materials more enjoyable, interesting, and challenging.

\section{Mind Mapping Technique}

Mind Mapping are considered as the effective way in teaching vocabulary. Mind mapping help and encourage many learners to sustain their interest and work. Mind mapping are highly motivating since they are amusing and at the same time tested. Mind mapping also teach creativity skill such as imagining and collecting more references and ideas.

According to De Porter, Readon, and Nourie (1999:175) Mind Mapping is creative note-taking method, which eases us to remember much information. The best mind mapping is colourful and used much pictures and symbols; usually like an art.

According to Trianto (2009:158) mind mapping is a concrete graphic illustration which indicates how a single concept related to other concept in the same categories. Mind mapping is a pattern which at least consists of picture, symbol and colour that will not just help the students to understand the vocabulary knowledge but also make the students feel good, enjoyable and attract their brain which at last leads them to have interest in mastery vocabulary knowledge.

\section{Teaching Vocabulary through Mind Mapping Technique}

According to Richards \& Renandya (2002:261) One of the other interesting techniques that teacher can use in teaching vocabulary is mind mapping. In addition, Graves (2008:56) points out that mind mapping is one of the most powerful approaches to teach vocabulary because it engages students in thinking about word relationship. This technique incorporates a variety of other memory strategies, they are grouping, using imagery, and also this technique is valuable for improving both memory and comprehension of a new word, even enrich their vocabulary. vocabulary:

According to Nation (2008:95), below are the steps to use mind mapping in teaching

a. The students work individually to categorized or to grouping the words that are related to the key word or topic.

b. Write a key word or topic, for example transportation.

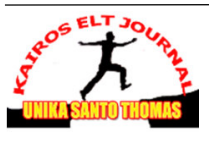


KAIROS ELT JOURNAL, Vol. 2, No. 2, August 2018

Copyright $\odot 2018$, ISSN: 2580-4278

c. Encourage the students to think of as many words as they can that are related to the key word or topic.

d. Guide the students to categorized and to grouping the words and get them to bring their own dictionaries

e. After the list of words is completed, discuss it with the students and sk the students to fill the blank columns the mind map on the board.

f. If the teacher wants to make sure that words are actually remember, asked the students to memorize that words.

g. And the last, do the review for each meeting

For example in teaching about transportation we can divide transportation into:

air, land, and water in a diagram like in the picture below. Then we might display the target words: airplane, van, bus, train, ship, and motorcycle. Next, begin instruction by having students brainstorm words related to the concept of transportation in air, land, and water. Finally, write what the words they have got on a whiteboard

\section{RESEARCH METHOD}

This study was Classroom Action Research (henceforth, CAR). The researcher uses the Classroom Action Research (CAR) model developed by Kemmis and Mc Taggart in Burns (2010:7). They state that there are four phases in each cycle for conduting Classroom Action Research (CAR) and the data of this study will analyze by using quantitative and qualitative analysis. The quantitative data will be collected by usig written test. While the qualitative data will be collected by using observation sheet, questionnaire, and field notes. Those phases are: planning, acting, observating, reflecting.

In Classroom Action Research there are three words must be explained, the first is research. Research is activity to observe an object with certain methodology to get data or information. The second is action, action is activity which intentional who conduct with certain provide. And the last is class, it is a group of students who receive lesson and taught by teacher in the same time.

\section{One group test design}

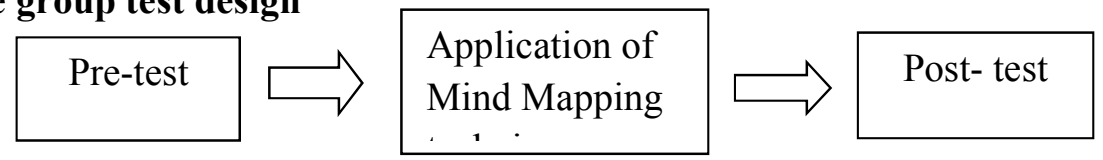

The subject of the study was first given an initial test (pre-test) to determine the extent of the students' initial abiliti before being given the learning using Mind Mapping technique. After being given the initial test, the teacher applies Mind Mapping technique in learning vocabulary. After Mind Mapping technique was applied in learning vocabulary, students were given a final test (post-test) to determine the extent to which students were leaarning vocabulary by using Mind Mapping technique.

\section{DATA ANALYSIS \\ The Quantitative Data}

The quantitative data was taken from the test result of students, namely pre-test before treatment, formative test after cycle one, and post-test after the end of cycle two. The complete result of the students' score in every test can be seen from the table and histogram of score interval and frequency.

\section{Students' Pre-test Score}

Table 1. Pre-test Score Interval

\begin{tabular}{|l|l|l|}
\hline Score Interval & Frequency & Percentage \\
\hline $35-41$ & 1 & $3,70 \%$ \\
\hline
\end{tabular}


KAIROS ELT JOURNAL, Vol. 2, No. 2, August 2018

Copyright $\odot 2018$, ISSN: 2580-4278

\begin{tabular}{|l|l|l|}
\hline $42-48$ & 0 & $0 \%$ \\
\hline $49-55$ & 3 & $11,11 \%$ \\
\hline $56-62$ & 7 & $25,92 \%$ \\
\hline $63-69$ & 4 & $14,81 \%$ \\
\hline $70-76$ & 12 & $44,44 \%$ \\
\hline $77-83$ & 0 & $0 \%$ \\
\hline Total & 27 & $100 \%$ \\
\hline
\end{tabular}

Scoring interval is found by applying formula:

Scoring Interval $(\mathrm{P})=\frac{x n-x 1}{1+3,3 \log n}$

Where:

- The division of distance $(\mathrm{R})=-x n$ ( the highest score) $x 1$ (The lowest score) in which, $x n=76$ and $x 1=35$

- The sum of whole data $(K)=1+3,3 \log n$

- $\mathrm{N}=$ The number of data, $\log _{27}=1,43$

Thus, $\mathrm{P}=\frac{76-35}{1+3.3 \log 27}=\frac{41}{6,14}==6,67=7$

From the table of pre-test score interval and frequency above, the writer presented the data histogram.

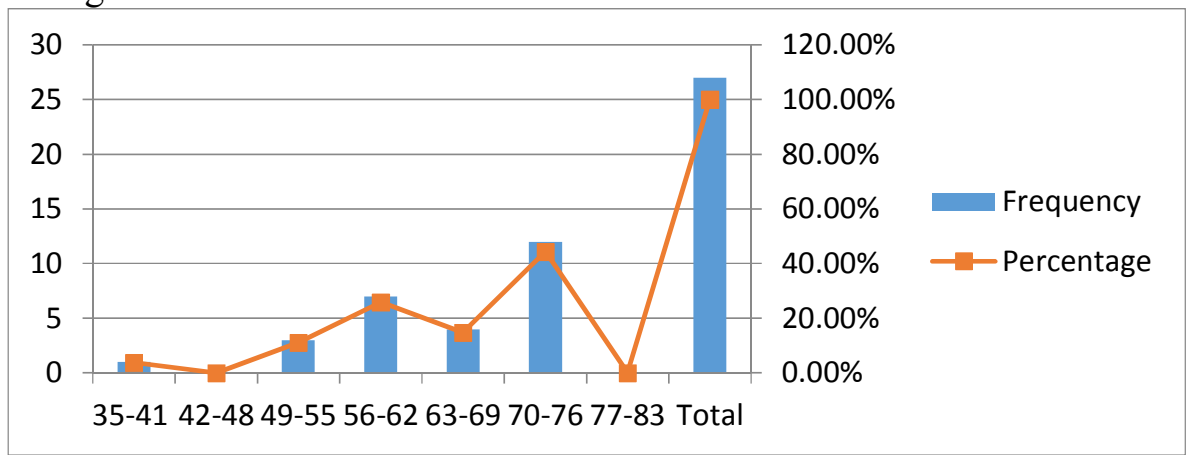

Figure 1. The Histogram of Pre-test Score

From the histogram of the pre-test score interval, the interval from 35-41 and the frequency was $1(3,70 \%)$. Then, interval from $42-48$ and the frequency was $0(0 \%)$. However, the interval from $49-55$ and the frequency was $3(11,11 \%)$. the interval from 56-62 was found 7 as frequency and the percentage was $25,92 \%$. Then, the interval 63-69 was found the percentage $14,81 \%$. the interval score from 70-76 was found 12 as frequency and the percentage was $44,44 \%$. Finally, the interval score from $77-83$ was found $0 \%$ as percentage of the students score of pre-test.

Students' Formative Test Score

Table 2. Formative Test Score Interval

\begin{tabular}{|l|l|l|}
\hline Score Interval & Frequency & Percentage \\
\hline $60-63$ & 3 & $11,11 \%$ \\
\hline $64-67$ & 6 & $22,22 \%$ \\
\hline $68-71$ & 3 & $11,11 \%$ \\
\hline $72-75$ & 4 & $14,81 \%$ \\
\hline $76-79$ & 2 & $7,40 \%$ \\
\hline $80-83$ & 8 & $29,62 \%$ \\
\hline $84-87$ & 1 & $3,70 \%$ \\
\hline
\end{tabular}

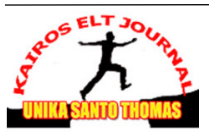


KAIROS ELT JOURNAL, Vol. 2, No. 2, August 2018

Copyright $\odot 2018$, ISSN: 2580-4278

Scoring interval is found by applying this following formula:

Scoring Interval $(\mathrm{P})=\frac{x n-x 1}{1+3,3 \log n}$

Where :

- The division of distance $(\mathrm{R})=x n$ ( the highest score) $-x 1$ (the lowest score) in which, $x n=86$ and $x 1=60$

- $\quad$ The sum of whole data $(K)=1+3,3 \log n$

- $\mathrm{N}=$ the number of the data, $\log _{27}=1,43$

Thus, so $\mathrm{P}=\frac{86-60}{1+3.3 \log 27}=\frac{26}{6,14}==4.23=4$

From the table of formative test score interval and frequency above, the writer presented the data in histogram.

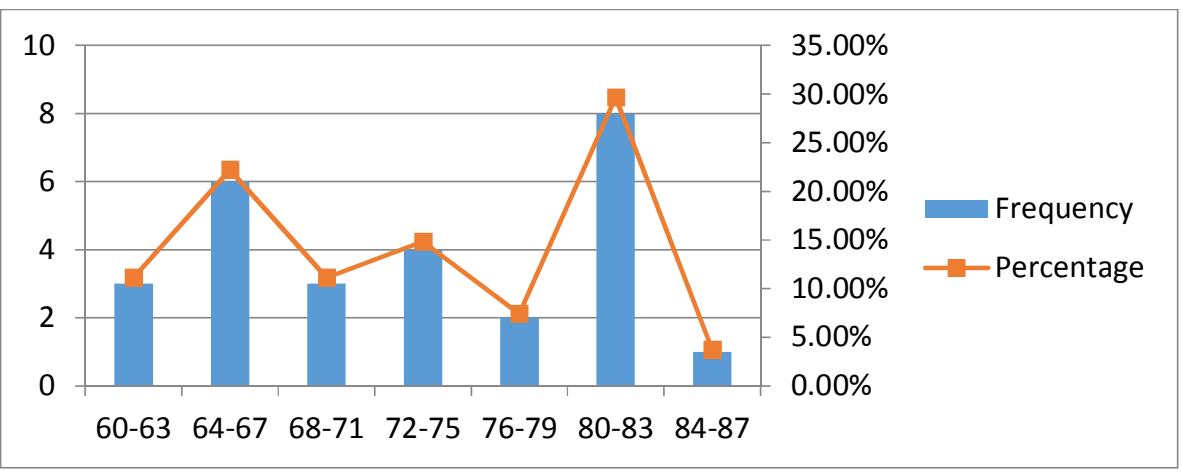

Figure 2. The Histogram of Formative Test

From the histogram of formative test score of percentage the writer found $11,11 \%$ as the interval score formative test was $60-63$ and the frequency was 3 . After that, the interval from 64-67 was found the percentage $22,22 \%$ and the frequency was 6 . Then, the interval from 68 71 , and it fell into the 3 frequency was found the percentage $11,11 \%$. Then, the highest frequency in formative test was found 6 and interval was from $72-75(14,81 \%)$. The interval from 76-79 was found 7,40\% as the percentage and the frequency was 2 . The interval from $80-$ 83 was found $29,62 \%$ as the percentage and the frequency was 8 . Finally, the interval $84-87$ was found $3,70 \%$ as the percentage and 1 as the frequency.

\section{Students' Post- Test Score}

Table 3. Post-Test Score Interval

\begin{tabular}{|l|l|l|}
\hline Score Interval & Frequency & Percentage \\
\hline $70-74$ & 3 & $11,11 \%$ \\
\hline $75-79$ & 4 & $14,81 \%$ \\
\hline $80-84$ & 6 & $22,22 \%$ \\
\hline $85-89$ & 4 & $14,81 \%$ \\
\hline $90-94$ & 0 & $0 \%$ \\
\hline $95-99$ & 2 & $7,40 \%$ \\
\hline $100-104$ & 8 & $29,62 \%$ \\
\hline
\end{tabular}

Scoring interval is found by applying this following formula:

Scoring interval $(\mathrm{P})=\frac{x n-x 1}{1+3,3 \log n}$

Where :

- The division of distance $(\mathrm{R})=x n$ ( the highest score) $-x 1$ (the lowest score) in which, $x n=100$ and $x 1=60$

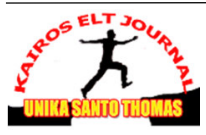


KAIROS ELT JOURNAL, Vol. 2, No. 2, August 2018

Copyright $\odot 2018$, ISSN: 2580-4278

- $\quad$ The sum of whole data $(K)=1+3,3 \log n$

- $\mathrm{N}=$ the number of the data, $\log _{27}=1,43$

Thus, so $\mathrm{P}=\frac{100-60}{1+3.3 \log 27}=\frac{40}{6,14}==6,51=7$

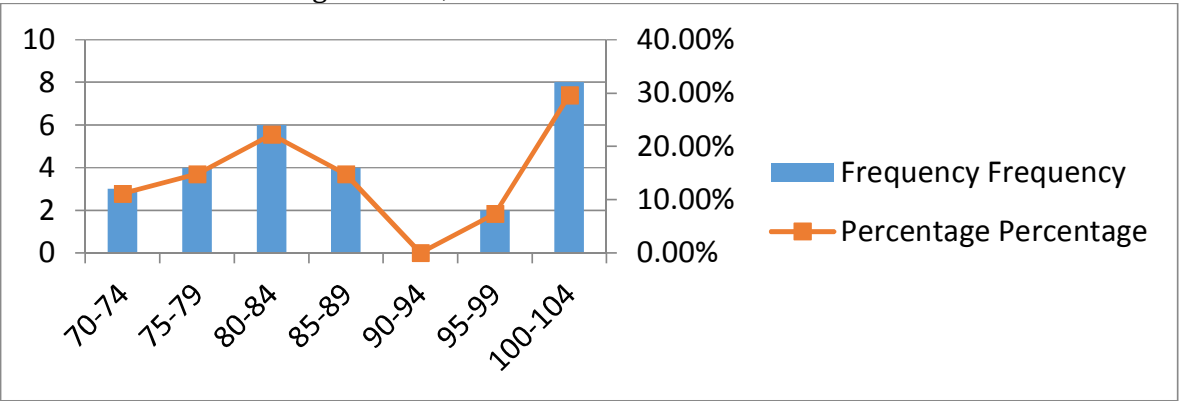

Figure 3. The Histogram of Post-Test

From the histogram of post-test score interval the writer found $11,11 \%$ interval from $70-74$ and the frequency was 3 . Then, the interval from 75-79 was found the frequency 4 $(14,81 \%)$. Next, the interval from $80-84$ was found the frequency 6 and found $22,22 \%$ as the percentage. Further, the interval from $85-89$ was calculated the prcentage $14,81 \%$ and found 4 as the frequency. The frequency score 0 was found on the interval $90-94$, the percentage was $0 \%$. The frequency 2 was found on interval $95-99$, the percentage was $7,40 \%$. Finally, the writer found 100-104 inerval and the frequency was $8(29,62 \%)$.

After that, the students' mean score from pre-test, formative test, and post-test can be seen as follows:

Table 4. Quantitative Data

\begin{tabular}{|l|l|l|l|}
\hline Component & Pre-test & Formative test & Post-test \\
\hline Mean & 65,33 & 72,59 & 85,92 \\
\hline Median & 65 & 75 & 85 \\
\hline Mode & 76 & 80 & 100 \\
\hline
\end{tabular}

The improvement of the studentsvocabulary by Mind Mapping Technique can be also seen from the mean of the students' score in the pre-test, formative test, and post test. Therefore, in order to know the improvement of all tests, the following formula was applied:

$\mathrm{X}=\frac{\sum X}{N}$

Where:

$\mathrm{X}=$ The mean of the students

$\sum X=$ The total of score

$\mathrm{N}=$ The number of the students

From the formula above, the result of the students' mean score could be seen as follows:

a. In the pre test, the total score of the students is $\frac{1764}{27}=65,33$

b. In the Formative test, the total score of the students is $\frac{1960}{27}=72,59$

c. In the post test, the total score of the students is $\frac{2320}{27}=85,92$

To find out the percentage of the students' improvment score, the writer applied the following formula:

$\mathrm{P}=\frac{y 1-y}{y} \times 100 \%$

Where:

$\mathrm{P}:$ percentage of students' improving

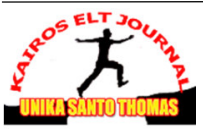


KAIROS ELT JOURNAL, Vol. 2, No. 2, August 2018

Copyright $\odot 2018$, ISSN: 2580-4278

y1: post-test result

$y$ : pre-test result

a. The percentage of students' improvement score from pre-test to post-test is :

$\mathrm{P}=\frac{y 1-y}{y} \times 100 \%$

$\mathrm{P}=\frac{85,92-65,33}{65,33} x 100 \%$

$\mathrm{P}=\frac{20,59}{65,33} x 100 \%$

$\mathrm{P}=31,51 \%$

Thus, the percentage of the stdents' improvement score from the pre-test to post-test is $31,51 \%$.

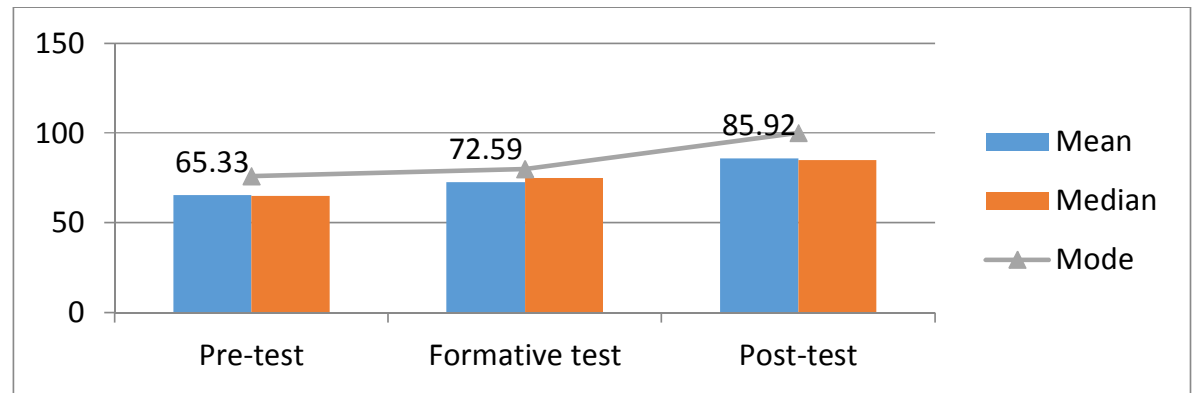

Figure 4. The Histogram of Quantitative Data

According to the histogram of quantitative data above, the students score increased. The mean score of the students in pre-test was 65,33 and it increased to into $72,59 \%$. After that, the score of post- test became $85,92 \%$. On the other hand, the median on the pre-test was 65 , the formative was 75 and the median of post-test was 85 . Finally, the mode score on the pretest was 76. It was no longer improved on the formative test 80 . At the end, the mode on the post-test was 100 . Therefore, the score had significantly increased from pre-test to post-test.

\section{Students Score Based on KKM}

In this study, the writer also calculated it in the form of the percentage of scoring standard to know the total of the students who passed the KKM. The writer used formula as follows: $\mathrm{P}=\frac{F}{N} X 100 \%$ The writer presentedthe students' data percentage who got the score $\geq 75$ through histogram. It was presented as follows

$\mathrm{P}=\mathrm{F}$ The writer presented the students' data percentages who got the score 70 through histogram. It was presented as follows:

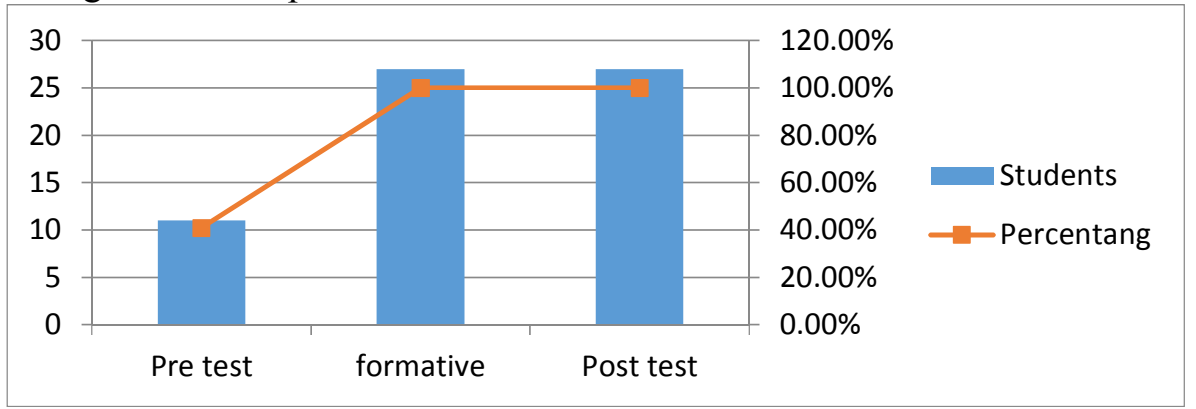

Figure 5. The Histogram of Students' Percentages Based on KKM

The percentage of the students who got the score $\geq 70$ showed the improvement of students' score from the first test (pre-test) until the last (post-test). The histogram above presented that the students' percentage who got score $\geq 70$. There was $40,74 \%$ (11 students)

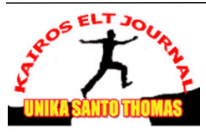


KAIROS ELT JOURNAL, Vol. 2, No. 2, August 2018

Copyright $\odot 2018$, ISSN: 2580-4278

passed KKM in pre-test. In formative test, there was 100\% (27students) passed KKM. Last, in post test, there was $100 \%$ (27 students) passed KKM and there were not passed KKM. It can be conclude that there was a significant improvement about $40,74 \%$ until $100 \%$ from pre-test to post-test.

\section{The Qualitative Data}

Te qualitative data was taken from observation sheet, field notes, and questionnaire and were prsented below.

\section{Observation sheet}

Observation sheet was focused on the situation of teaching learning process including the students' activities, behavior and interaction in the classroom. The observation sheet was made by the writer and it checked by the teacher who acted as the collaborator and observed the teaching learning process in the cycle 1 and cycle 2 . The data can be seen as follows:

Table 5. Observation Sheet II Cycle 1 and Cycle II

\begin{tabular}{|c|c|c|c|c|}
\hline \multirow[t]{2}{*}{ CRITERIA } & \multicolumn{2}{|c|}{ Cycle I } & \multicolumn{2}{|c|}{ Cycle II } \\
\hline & YES & NO & YES & NO \\
\hline \multicolumn{5}{|l|}{ TEACHER } \\
\hline $\begin{array}{lll}\text { 1. The teacher } & \text { prepares } \\
\text { teaching } & \text { material } \\
& \text { systematically. }\end{array}$ & $\sqrt{ }$ & & $\sqrt{ }$ & \\
\hline $\begin{array}{l}\text { 2. The teacher explains the } \\
\text { objectives of teaching. }\end{array}$ & $\sqrt{ }$ & & $\sqrt{ }$ & \\
\hline $\begin{array}{l}\text { 3. The teacher does } \\
\text { brainstorming to } \\
\text { introduce the concept }\end{array}$ & $\sqrt{ }$ & & $\sqrt{ }$ & \\
\hline $\begin{array}{l}\text { 4. The teacher explains the } \\
\text { material clearly. }\end{array}$ & $\sqrt{ }$ & & $\sqrt{ }$ & \\
\hline $\begin{array}{l}\text { 5. The teacher responds the } \\
\text { students' questions and } \\
\text { gives chance to all } \\
\text { students to ask the } \\
\text { concept }\end{array}$ & $\sqrt{ }$ & & $\sqrt{ }$ & \\
\hline $\begin{array}{l}\text { 6. The teacher forms the } \\
\text { students in several } \\
\text { groups }\end{array}$ & $\sqrt{ }$ & & $\sqrt{ }$ & \\
\hline $\begin{array}{l}\text { 7. The teacher gives the } \\
\text { students a concept, } \\
\text { topic, or idea. }\end{array}$ & $\sqrt{ }$ & & $\sqrt{ }$ & \\
\hline $\begin{array}{l}\text { 8. The teacher asks the } \\
\text { students write the } \\
\text { concept in their team } \\
\text { paper. }\end{array}$ & $\sqrt{ }$ & & $\sqrt{ }$ & \\
\hline $\begin{array}{l}\text { 9. Teacher asks the students } \\
\text { write words that related } \\
\text { to the concept as many as } \\
\text { they can. }\end{array}$ & $\sqrt{ }$ & & $\sqrt{ }$ & \\
\hline $\begin{array}{l}\text { 9. The teacher manages } \\
\text { time effectively and } \\
\text { efficiently. }\end{array}$ & $\sqrt{ }$ & & $\sqrt{ }$ & \\
\hline \multicolumn{5}{|l|}{ STUDENTS } \\
\hline $\begin{array}{l}\text { 1. The students pay attention to } \\
\text { the teacher's explanation. }\end{array}$ & $\sqrt{ }$ & & $\sqrt{ }$ & \\
\hline
\end{tabular}


KAIROS ELT JOURNAL, Vol. 2, No. 2, August 2018

Copyright $\odot 2018$, ISSN: 2580-4278

\begin{tabular}{|c|c|c|}
\hline $\begin{array}{l}\text { 2. The students ask the teacher } \\
\text { if there is something unclear. }\end{array}$ & $\sqrt{ }$ & $\sqrt{ }$ \\
\hline $\begin{array}{l}\text { 3. The students are divided into } \\
\text { several group. }\end{array}$ & $\sqrt{ }$ & $\sqrt{ }$ \\
\hline 4. The students write the topic. & $\sqrt{ }$ & $\sqrt{ }$ \\
\hline $\begin{array}{l}\text { 5. The students write the words } \\
\text { that related to the concept. }\end{array}$ & $\sqrt{ }$ & $\sqrt{ }$ \\
\hline $\begin{array}{l}\text { The students feel interested } \\
\text { in teaching learning process. }\end{array}$ & $\sqrt{ }$ & $\sqrt{ }$ \\
\hline $\begin{array}{l}\text { 7. The students do exercises } \\
\text { seriously. }\end{array}$ & $\sqrt{ }$ & $\sqrt{ }$ \\
\hline SITUATION & & \\
\hline $\begin{array}{l}\text { 1. The classroom is } \\
\text { comfortable (clean, } \\
\text { calm, and organized). }\end{array}$ & $\sqrt{ }$ & $\sqrt{ }$ \\
\hline $\begin{array}{l}\text { 2. The classroom is not } \\
\text { noisy. }\end{array}$ & $\sqrt{ }$ & $\sqrt{ }$ \\
\hline $\begin{array}{l}\text { 3. The classroom has } \\
\text { teaching aids } \\
\text { (whiteboard, marker, } \\
\text { and proyektor). }\end{array}$ & $\sqrt{ }$ & $\sqrt{ }$ \\
\hline
\end{tabular}

\section{Field Notes}

In this study, the writer also used the field notes as the instrument of collecting the data during the teaching and learning process. The writer observed the activity of the students during the implementation of Mind Mapping Technique to improving vocabulary mastery after implementing this technique. The detail of the process could be seen as follows:

\section{The First Meeting: Friday, August $31^{\text {th }}, 2018$}

In the first meeting, the writer did pre-test before implementing the classroom action research (CAR). It was used to measure the students' vocabulary mastery. It started from 09.15am until 10.45am. In the first meeting, the English teacher and the writer came together to the class. The writer introduced herself and the purpose of the research to the students. Then, the writer called the students name on the attendance list to know how many students present at the day and to get closer to the students. After that, the writer asked the students to answer the questions for 45 minutes before treatment and implemented the new technique that is Mind Mapping technique. Therefore, the writer asked them to answer what they known and not forced them. After time was over, the writer asked the students to collect their paper. After the pre-test finished, the writer said good bye.

\section{The Second Meeting: Wednesday, September $5^{\text {th }} 2018$}

The second meeting was the beginning of cycle I. it started from $12.15 \mathrm{pm}$ until $13.45 \mathrm{pm}$. The writer opened the class by greeting the students, the chairman lead prayer, and checked the attendance list of students. after that, the writer prepared the teaching material before starting to teach vocabulary, and also developed teaching process through the activity of students in the classroom. After that, the writer started to teach vocabulary based on the problem faced by students toward vocabulary mastery taken from the result of pre-test.

The writer introduced a new technique in learning vocabulary, Mind Mapping technique, and started the teaching learning process. The students began to be interested in learning because the writer gave them handouts of incomplete vocabulary test. Then, the writer divided the students into eight group the students. After that, the writer asked to learn the material.

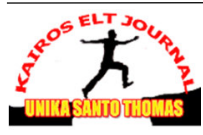


KAIROS ELT JOURNAL, Vol. 2, No. 2, August 2018

Copyright $\odot 2018$, ISSN: 2580-4278

\section{The Third Meeting: Friday, Sept $7^{\text {th }}, 2018$}

The third meeting was the second meeting of teaching and learning process in cycle I. It started from $09.15 \mathrm{am}$ until $10.45 \mathrm{am}$. The writer continued the previous material about vocabulary. Then, the writer reviewed it by asking students one by one to prove whether the students still remembered material about what the writer explained the last day. After finishing it, the writer continued to explain to the students about the use of Mind Mapping technique in learning vocabulary.

\section{The Fourth Meeting: Wednesday, Sept $12^{\text {th }}, 2018$}

The fourth meeting was the third meeting of teaching learning process in cycle 1 and also the last stage in the CAR for cycle 1. It started from 12.15 am until $13.45 \mathrm{am}$. In this time, the writer gave the second test namely Formative test to the students. The writer gave 30-40 minutes to finished.

\section{The Fifth Meeting :Friday, Sept $14^{\text {th }}, 2018$}

The fifth meeting was the first meeting of teaching and learning process in cycle II. It started from 09.15-10.45 am. Based on the result of the formative test in the fourth meeting, the writer gave feedback and appreciation to the students because they had done their best although there were some students still confused about vocabulary. In this time, the writer asked them to be serious on the writers' explanation about the vocabulary.

\section{The Sixth Meeting: Wednesday, Sept $19^{\text {th }}, 2018$}

The sixth meeting was the second meeting of teaching and learning process in cycle II. It started from 09.15 until $10.45 \mathrm{am}$. After doing the reflection in the fifth meeting, the writer started the class again with the topic that were animal, job, and transportation. In this meeting the writer gave the students 30 minutes to did the task. After finishing the task, the writer and the students was check their result together. Then, the writer asked the students one by one to mention the vocabulary of the topic.

\section{The Seventh Meeting:Friday, Sept $21^{\text {th }}, 2018$}

The seventh meeting was the third meeting of teaching and learning process in cycle II. It is started from 09.15 until $10.45 \mathrm{am}$. In this meeting was continued from the last meeting. In this meeting, the writer explained the students Mind Mapping technique clearly. The students seemed more understand and more active and created a good relationship with their group members. All the students participated in discussing the topic.

\section{The Eighth Meeting: Wednesday, Sept $26^{\text {th }}, 2018$}

The eighth meeting was the end of the whole cycle in which students were asked to do a test. It started from 12.15 until $13.45 \mathrm{am}$. In this meeting, the writer did the last test (post test) to the students. The test was in multiple with the topic animal, job, and transportation. It was carried out in 30 until 50 minutes. After that, the writer asked them to collect it. So that the writer could assess and saw the progress of using this technique. And the end the writer said thank you and good bye to the students.

\section{Questionnaire}

The questionnaire was conducted after bothof cycle done. From the questionnaire the writer found out the students' respons which were taugh by using Mind Mapping technique whether it was appropriate with improvement of students' vocabulary mastery skill or not. The questionnaire was used to know the students' response toward, Mind Mapping technique that 
KAIROS ELT JOURNAL, Vol. 2, No. 2, August 2018

Copyright $\odot 2018$, ISSN: 2580-4278

writer applied. The students were asked to give the answer is the category of Strongly Disagree, Disagree, Agree, Strongly Agree. The students' response can be seen as follows:

Table 6. Questionnaire of Students' Response on Mind Mapping technique

\begin{tabular}{|c|c|c|c|c|c|c|}
\hline No & Statements & $\begin{array}{l}\text { Strongly } \\
\text { Disagree }\end{array}$ & Disagree & Agree & $\begin{array}{l}\text { Strongly } \\
\text { Agree }\end{array}$ & $\begin{array}{l}\text { The number } \\
\text { of students }\end{array}$ \\
\hline 1 & $\begin{array}{l}\text { Saya menyukai } \\
\text { pelajaran Bahasa } \\
\text { Inggris meskipun } \\
\text { agak sulit }\end{array}$ & $\begin{array}{l}1 \\
3,70 \%\end{array}$ & $\begin{array}{l}2 \\
7,40 \%\end{array}$ & $\begin{array}{l}7 \\
25,92 \%\end{array}$ & $\begin{array}{l}17 \\
62,96 \%\end{array}$ & \multirow{5}{*}{27} \\
\hline 2 & $\begin{array}{l}\text { Mind Mapping } \\
\text { technique ini } \\
\text { merupakan hal } \\
\text { baru bagi saya }\end{array}$ & 0 & $\begin{array}{l}5 \\
18,51 \%\end{array}$ & $\begin{array}{l}7 \\
25,92 \%\end{array}$ & $\begin{array}{l}15 \\
55,55 \%\end{array}$ & \\
\hline 3 & $\begin{array}{l}\text { Saya menyukai } \\
\text { pembelajaran } \\
\text { dengan } \\
\text { menggunakan } \\
\text { Mind Mapping } \\
\text { technique }\end{array}$ & 0 & $\begin{array}{l}1 \\
3,70 \%\end{array}$ & $\begin{array}{l}23 \\
85,18 \%\end{array}$ & $\begin{array}{l}3 \\
11,11 \%\end{array}$ & \\
\hline 4 & $\begin{array}{l}\text { Penggunaan Mind } \\
\text { Mapping } \\
\text { technique } \\
\text { mempermudah } \\
\text { saya dalam } \\
\text { menguasai } \\
\text { kosakata }\end{array}$ & 0 & $\begin{array}{l}2 \\
7,40 \%\end{array}$ & $\begin{array}{l}20 \\
74,07 \%\end{array}$ & $\begin{array}{l}5 \\
18,51 \%\end{array}$ & \\
\hline 5 & $\begin{array}{l}\text { Teknik ini bisa } \\
\text { membantu saya } \\
\text { dalam menguasai } \\
\text { kosakata }\end{array}$ & 0 & 0 & $\begin{array}{l}15 \\
55,55 \%\end{array}$ & $\begin{array}{l}12 \\
44,44 \%\end{array}$ & \\
\hline
\end{tabular}

From the table 6, it can be seen that students' responses, the analysis of each item could be described as follows.

The first item stated the students like English subject. The result of the questioner showed $17(62,96 \%)$ students strongly agreed with this statement, $7(25,92 \%)$ students was agree, $2(5,55 \%)$ students did not quite agree and $1(3,70 \%)$ disagree. It could be concluded that basically most of them like English Subject.

The second item stated the students are intrested in Mind Mapping technique. 15 $(55,55 \%)$ students strongly agree with the statement. $7(25,92 \%)$ was agreed. $5(18,51 \%)$ students disagree. While there was no students who strongly disagree to the first statement. It could be concluded most of students was interesting with this strategy.

The third item ststed that the students enjoyed learning through in Mind Mapping technique. The result showed $3(11,11 \%)$ students strongly agree, $0(\%)$ did not quite agree, 1 $(3,70 \%)$ disagree, and there was no students who strongly disagree this statement.

The fourth item stated that the use of Mind Mapping technique makes it easier for students to vocabulary. 5(18,51\%) students strongly agree, $20(74,07 \%)$ agree, 2(7,40) disagree, and there was no students who strongly disagree this statement. 
KAIROS ELT JOURNAL, Vol. 2, No. 2, August 2018

Copyright $\odot 2018$, ISSN: 2580-4278

The last item stated that Mind Mapping technique can help students in English leson. There were $12(44,44 \%)$ students strongly agree, $15(55,55 \%)$ did not quite agree, and there was no students who disagree and strongly disagree this statement. It showed that Mind Mapping technique was good to be applied in English lesson.

Based on the questionnaire analysis above, the writer conclude that not at also writing a all the students on SMP Santo Thomas 3 Medan students like English subject and also vocabulary even though some students was disagree like writing and said English in their school was no enjoyable but applying Mind Mapping technique helped to improve their skill in vocabulary.

\section{Discussion}

In conducting the pre-test the students' mean score vocabulary before implementing the classroom action research was 65,33\%. Moreover, there were 11 students who passed the KKM. On the other hand, the class percentage who passed the KKM was 40,74\%. It means that there were 16 students out of target.

Then, the mean score of the formative test which was conducted on the last cycle one was 72,59. It could be seen that there were some improvements from previous test (pre-test). On the other hand the percentage that the passen the KKM was $92,59 \%$. It could be seen that there where 25 students who fulfill the target. Therefore, the students wee needed to improve more because they could not achive the target yet succes classroom action reserch. That was thw reaseon why the writer continued to the second cycle..

However, the mean score on the post-test which was conducted on the cycle 2 was $85,92 \%$. It showed by students' improvement from formative test to the post test. The post test had fullfilled the target of CAR, most of the students could pass the the citerion of minimum completnrsess.

In conclusion, Mind Mapping technique a suitable to improve students' skill in vocabulary because this techniquecan make they were easy to understand and enjoy materials bacause they discuss it with their groups. After that, students can be more comfortable with with condition of the class bacause they were let go be more active without ignoring individual score. Based on the result of qualitative and quantitative data, it was found that the application of Mind Mapping technique successfully improved students achievement vocabulary.

\section{CONCLUSIONS}

After presenting and analyzing data in the previous chapter, the writer draws the conclusion as follows:

1. The result of the study showed that Mind Mapping technique works effectively on improving students' vocabulary mastery. The improvement could be seen from the students' mean score of pre-test, namely 65,33 in formative test namely 72,59 and in posttest namely 85,92.

2. The students' responses were very good. They felt enthusiastic and motivated after being taught with Mind Mapping technique. It could be seen from the qualitative data such as observation and field notes during the study.

\section{BIBLIOGRAPHY}

Benjamin, A. \& Crow, Jhon T. 2009. Vocabulary at the Center. Portland: Stenhouse Publisher.

Bruns, A. 2010. Doing Action Research in English Language Teaching:A Guide for Practicioners. New York : Routledge. 
KAIROS ELT JOURNAL, Vol. 2, No. 2, August 2018

Copyright $\odot 2018$, ISSN: 2580-4278

Broomley, K. 1992. Language Arts : Exploring Connection $\left(2^{\text {nd }}\right.$ Ed). Boston : Simon \& Schuster.

Capello, M. \& Moss, Barbara.2010. Contemporary Readings in Literary Education. Los Angeles: Sage Publications.

Graves, M. 2008. Insruction on Individual Words : One Size Does Not Fit All. New York : International Reading Association.

Jones, P. W. 2012. Vocabulary 1 Games and Activity. New Edition. England: Penguin English

Jordan, R. 1997.English for Academic Purpose.Cambridge: Cambridge University Press

Linse, C. 2005. Practical English Language Teaching : Young Learners. New York:McGrawHill Companie.

Liu, G.H. 2016. Application of Mind Mapping Method in College English Vocabulary Teaching. Open Journal of Modern Linguistics, 6 (3),202-206.

Mamura, P. Z. 2011. The Use of Mind Mapping to Improve Vocabulary Mastery of the Fourth Grade Students of SMP Muhammadiyah Ngijon 1 in the Academic Year of 2010/2011. Anpublished Sarjana's Thesis, Faculty of Teachers Training and Education: State University of Yogyakarta.

Nation, P. 2001. Learning Vocabulary in Anther Language. Cambridge : Cambridge University Press.

2008. Teaching Vocabulary: Strategies and Techniques. Boston: Heinle Cengage Learning.

Nunan, D. 2003. Practical English Language Teaching. New York:McGraw-Hill.

O’Malley and Pierce. 1996. Authentic Assessment for English Language Learners: Practical Approaches for Teachers. New York: Addison-Wesley Publishing.

Richards, J. C. \& Renandya, W. A. 2002. Methodology in Language Teaching: An Anthology of Current Practice. Cambridge : Cambridge University Press.

Rubin, D. 1993. Teaching Reading and Study Skill in Content Area. Boston: Simon \& Schuster.

Schmitt, M. 2000.Vocabulary in Language Teaching.Cambridge : Cambridge University Press.

Schrivener, J. 1994. Learning Teaching. London: Heinman Publisher.

Shepherd, J. 1980. Measuring Second Language Acquisition. London : Short Run Press.

Taylor, L. 1990. Teaching and Learning Vocabulary. New York: Pearson Education.

Thornburry, S. 2002. How to Teach Vocabulary. Harlow : Pearson Education.

Tonni Limbong. (2018). PENDIDIKAN BERBASIS IT DAN ETIKANYA . Jayapangus Press, 1(1), 52-79.

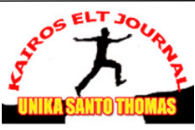


KAIROS ELT JOURNAL, Vol. 2, No. 2, August 2018

Copyright $@$ 2018, ISSN: 2580-4278

Trianto, M.Pd. 2009. Mendesain Model Pembelajaran Inovatif: Konsep, Landasan, dan Implementasinya pada Kurikulum Tingkat Satuan Dasar Pendidikan (KTSP). Jakarta: Kencana.

Wisnawa, G. 2013. Improving Vocabulary Mastery through Mind Mapping of the Seventh Grade Students of SMP Silachandra In Academic Year 2012/2013. Anpublished Sarjana's Thesis, Faculty of Teachers Training and Education: State Mahasaraswati Denpasar University.

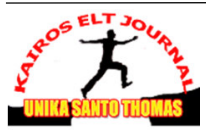

